\title{
Profil kemampuan berpikir kreatif matematis ditinjau dari gaya kognitif reflective dan impulsive
}

\author{
Asih Miatun *, Nurafni Nurafni \\ Program Studi Pendidikan Matematika, Universitas Muhammadiyah Prof. DR. HAMKA. \\ Jalan Tanah Merdeka No. 20, Kp Rambutan, Ciracas, DKI Jakarta 13830, Indonesia. \\ *E-mail: asihmiatun@uhamka.ac.id \\ * Corresponding Author
}

\section{ARTICLE INFO}

\section{Article history}

Received: 14 July 2019;

Revised: 9 Dec. 2019;

Accepted: 20 Dec. 2019

\section{Keywords}

berpikir kreatif matematis; gaya kognitif; reflektif; impulsive; mathematical creative thinking; cognitive style; reflective; impulsive

\section{ABSTRACT}

Penelitian ini bertujuan untuk mendeskripsikan profil kemampuan berpikir kreatif matematis mahasiswa calon guru dalam menyelesaikan masalah openended ditinjau dari gaya kognitif reflective dan impulsive. Penelitian ini adalah penelitian deskriptif kualitatif. Subjek penelitian ini adalah mahasiswa calon guru pada Program Studi Pendidikan matematika, Universitas Muhammadiyah Prof. DR. HAMKA yang diambil menggunakan teknik purposive sampling. Validasi data menggunakan teknik triangulasi waktu. Data dianalisis menggunakan metode perbandingan tetap (constant comparative method) dengan langkah (1) reduksi data dan kategorisasi, (2) penyajian data; dan (3) penarikan kesimpulan dan verifikasi. Hasil penelitian menunjukkan bahwa dari empat indikator kemampuan berpikir kreatif matematis, mahasiswa dengan gaya kognitif reflective mampu memenuhi aspek kelancaran dan keterincian, yaitu menjawab soal dengan lebih lancar, mampu menjelaskan hubungan sebab akibat antar konsep yang digunakan, serta lebih rinci dan runtut dalam menjawab dan menjelaskan jawaban tertulisnya, dibandingkan dengan mahasiswa dengan gaya kognitif impulsive. Indikator aspek keluwesan dan kebaruan masih belum bisa terpenuhi karena mahasiswa dengan gaya kognitif reflective dan impulsive baru mampu menjawab pertanyaan menggunakan satu cara saja dan belum menggunakan strategi baru.

The study aimed to describe mathematical creative thinking ability profiles of prospective students in solving open-ended problems in terms of reflective and impulsive cognitive styles. The research classified as a qualitative descriptive study. The subjects of this study were prospective students of the Mathematics Education Department, Universitas Muhammadiyah Prof. DR. HAMKA and selected using a purposive sampling technique. For data validation, we used time triangulation techniques. Data were analyzed using the constant comparison method with steps (1) data reduction and categorization; (2) data presentation; and (3) conclusions and verification. The results showed that from the four indicators of mathematical creative thinking, students with reflective cognitive style were able to fulfill fluency and detail aspects in answering questions, explain causal relationships between concepts used, and more detail in written answers, compared to students with impulsive cognitive style. The indicators of flexibility and originality aspects of both students with the reflective and impulsive cognitive style are still cannot be fulfilled because they only answer questions using one method without using a new strategy.

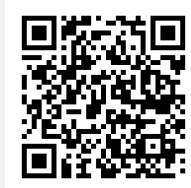
This is an open access article under the CC-BY-SA license.

How to Cite: Miatun, A., \& Nurafni, N. (2019). Profil kemampuan berpikir kreatif matematis ditinjau dari gaya kognitif reflective dan impulsive. Jurnal Riset Pendidikan Matematika, 6(2), 150-164.

doi:https://doi.org/10.21831/jrpm.v6i2.26094 


\section{PENDAHULUAN}

Pembelajaran matematika abad 21 menuntut kemampuan siswa untuk menguasai 4 keterampilan matematika yaitu, creativity (kreativitas), critical thinking (kemampuan berpikir kritis), communication (komunikasi), dan collaboration (kolaborasi) atau yang lebih dikenal dengan $4 \mathrm{C}$ abad 21. Salah satu dari keterampilan 4C adalah kreativitas. Dalam matematika sering disebut dengan istilah keterampilan berpikir kreatif matematis. Kemampuan berpikir kreatif matematis menjadi salah satu kebutuhan dalam pendidikan matematika untuk menyelesaikan masalah dalam rangka menemukan banyak ide dan solusi baru sehingga dapat diperoleh penyelesaian yang tepat atas masalah tersebut (Apriliani et al., 2016).

Hasil penelitian Rochmad et al. (2018) menyebutkan bahwa mahasis-wa pendidikan matematika mengalami kesulitan dalam berpikir kreatif dan kritis. Sedangkan beberapa peneliti lain (misalnya Ayllón et al., 2016; Sanders, 2016) menyebutkan bahwa prioritas guru saat ini adalah mengidentifikasi dan mengembangkan kreativitas. Oleh karena itu guru maupun calon guru harus memiliki keterampilan berpikir kreatif matematis. Mahasiswa yang nantinya akan menjadi seorang guru juga harus memiliki kemampuan berpikir kreatif matematis agar nantinya mampu mengembangkan kreativitas siswa yang dididiknya. Hal tersebut sejalan dengan pendapat Suastika (2017) bahwa guru matematika dituntut untuk mengembangkan kemampuan berpikir kreatif matematis dalam pembelajaran, sehingga siswa dapat membangun bakat matematikanya.

Hasil penelitian Kadir dan Masi (2014) menyebutkan bahwa untuk membuat siswa menjadi kreatif, guru harus menjadi kreatif terlebih dahulu. Cara mengajar guru merupakan salah satu faktor penyebab mengapa siswa menjadi kurang kreatif (Winda et al., 2018). Pengajuan ide yang kreatif dan inovatif dalam pembelajaran matematika dapat meningkatkan kemampuan berpikir kreatif siswa. Siswono (2010) mengemukakan bahwa kemampuan berpikir kreatif dalam pemecahan masalah matematika dapat dapat dinilai oleh empat komponen yaitu fluency (kelancaran), flexibility (fleksibilitas), originality (kebaruan), dan elaboration (keterincian). Keterampilan berpikir kreatif matematis siswa menjadi lebih baik jika pembelajaran dihadapkan dengan proses pemecahan masalah (Hendriana \& Fadhillah, 2019). Brigg dan Davis menyebutkan bahwa salah satunya untuk memfasilitasi pengajuan ide kreatif itu adalah dengan memberikan masalah open-ended (Damayanti \& Sumardi, 2018).

Masalah open-ended adalah masalah terbuka yang penyelesaiannya membutuhkan kemampuan berpikir kreatif. Ariani et al. (2014) dalam penelitiannya melaporkan bahwa open-ended problem memberikan pengaruh yang signifikan terhadap kemampuan pemecahan masalah matematika dan kemampuan kreativitasnya. Melalui masalah open-ended kemampuan matematika dapat meningkat (Azis, 2018; Kurniawan et al., 2018; Maharani, 2014; Yuniarti et al., 2017). Sariningsih dan Herdiman (2017) dalam penelitiannya juga melaporkan bahwa kemampuan berpikir kreatif matematis siswa yang mendapat pembelajaran berbasis masalah terbuka lebih baik dari pada siswa yang mendapatkan pembelajaran konvensional. Burghes dan Robinson (Mihajlović \& Dejić, 2015) menyebutkan ada beberapa keuntungan menggunakan masalah open-ended, yaitu siswa berpartisipasi lebih aktif dalam proses belajar mengajar, siswa bisa lebih sering mengekspresikan ide-ide yang mereka miliki, setiap siswa menjawab masalah dengan caranya sendiri dan unik, dan siswa dapat mengembangkan kemampuan berpikir kreatif.

Gaya kognitif merupakan salah satu variabel belajar yang perlu dipertimbangkan dalam melaksanakan suatu proses pembelajaran. Fadiana (2016) yang menyebutkan bahwa keberhasilan menerima pesan matematika juga ditentukan oleh gaya kognitif. Lahinda dan Jailani (2015) menyebutkan bahwa gaya kognitif sebagai kontrol kognitif adalah bagaimana seseorang mengambil keputusan pada suatu hal yang akan dilakukan, baik itu berupa rencana maupun dalam mengambil keputusan. Sudia dan Lambertus (2017) menyebutkan bahwa gaya kognitif yang pertama kali ditemukan adalah gaya kognitif reflective dan impulsive. Seseorang dengan gaya kognitif reflective selalu berpikir dahulu jika dihadapkan dengan masalah atau pertanyaan, sedangkan seseorang dengan gaya kognitif impulsive cenderung spontan dalam menjawab pertanyaan dan menulis semua ide maupun rencana yang ada dalam pikirannya (Aprilia et al., 2015; Rozencwajg \& Corroyer, 2005). Kagan (Sudia et al., 2014) menyebutkan bahwa seseorang yang memiliki karakteristik cepat dalam menjawab pertanyaan tetapi tidak hati-hati atau menjawab salah, disebut dengan gaya kognitif impulsive. Sedangkan seseorang yang memiliki karakteristik lambat dalam merespon masalah tetapi lebih berhati-hati atau teliti, sehingga jawaban yang dihasilkan cenderung diperbaiki, disebut memiliki gaya kognitif reflective. 


\section{Jurnal Riset Pendidikan Matematika, 6 (2), 2019 - 152}

Asih Miatun, Nurafni Nurafni

Berdasarkan apa yang telah dikemukakan sebelumnya, dapat dipahami bahwa tipe gaya kognitif reflektif dan impulsif memberikan gambaran tentang bagaimana kecepatan dan kesiapan seseorang merespon suatu masalah atau tantangan. Kaitannya dengan kreativitas seseorang, gaya kognitif tersebut akan mempengaruhi tindakan yang akan dilakukan seseorang dalam merencanakan berbagai ide kreatif. Karena guru matematika perlu mempertimbangkan gaya kognitif siswa dalam menyiapkan pembelajaran di kelas (Hooda \& Devi, 2017), maka guru maupun calon guru perlu mengetahui karakteristik dari gaya kognitif yang dimilikinya. Hal inilah yang menjadi salah satu pertimbangan bahwa kreativitas calon guru bisa di analisis berdasarkan gaya kognitifnya. Berdasarkan hal tersebut, maka tujuan dari penelitian ini adalah untuk mendeskripsikan profil kemampuan berpikir kreatif matematis mahasiswa calon guru yang bergaya kognitif reflective dan impulsive dalam menyelesaikan masalah open-ended.

\section{METODE}

Jenis penelitian yang dilakukan adalah penelitian deskriptif kualitatif. Penelitian ini dilakukan di Universitas Muhammadiyah Prof. Dr. HAMKA (UHAMKA). Subjek dalam penelitian ini adalah mahasiswa semester dua tahun ajaran 2018/2019 di Program Studi Pendidikan Matematika, Fakultas Keguruan dan Ilmu Pendidikan, UHAMKA. Mahasiswa semester awal perlu diketahui kemampuan berpikir kreatifnya, sehingga untuk pembelajaran ke depan dosen bisa mengembangkan kemampuan berpikir kreatif mahasiswa calon guru tersebut.

Peneliti adalah instrumen utama dalam penelitian ini. Instrumen bantu pada penelitian ini adalah MFFT (Matching Familiar Figure Test) dan soal tes kemampuan berpikir kreatif matematis pada mata kuliah Geometri Euclid. Tes kemampuan berpikir kreatif terdiri dari empat soal yang sebelumnya sudah divalidasi oleh dosen pendidikan matematika FKIP UHAMKA. Soal TKBKM disusun dengan berdasarkan indikator sebagai berikut: (1) aspek kelancaran (fluency) dengan menyatakan hubungan sebab akibat konsep matematis yang digunakannya; (2) aspek keluwesan (flexibility) dengan menggunakan berbagai macam strategi untuk menyelesaikan masalah; (3) aspek kebaruan (originality) dengan menggunakan strategi baru, unik,dan tidak biasa untuk menyelesaikan masalah matematika; dan (4) aspek keterincian (elaboration) dengan kemampuan menjelaskan secara terperinci, runtut, koheren terhadap suatu prosedur matematis dan jawaban.

Untuk menentukan subjek penelitian mahasiswa calon guru, penelitian ini menggunakan instrumen Matching Familiar Figure Test (MFFT) yang dirancang dan dikembangkan oleh Warli (2010) yang telah terbukti validitas dan reliabilitasnya. MFFT digunakan untuk menggolongkan mahasiswa calon guru yang mempunyai gaya kognitif reflective dan gaya kognitif impulsive. MFFT terdiri atas 13 soal bergambar ditambah dengan dua soal percobaan. Pada setiap nomor soal terdapat delapan variasi gambar dengan hanya satu gambar diantaranya yang sama dengan gambar standar. Tugas dari mahasis-wa adalah memilih salah satu dari variasi gambar yang tersedia (sampai diperoleh jawaban benar). Salah satu contoh soal MFFT disajikan pada Gambar 1.

Pemilihan subjek pada penelitian ini berdasarkan hasil tes perbedaan gaya kognitif reflective dan impulsive. Dipilih sekurang-kurangnya satu mahasiswa untuk setiap kategori dengan menggunakan teknik purposive sampling. Subjek yang terpilih adalah mahasiswa yang memiliki kemampuan awal sama. Subjek terpilih diberikan tes kemampuan berpikir kreatif matematis dan diwawancarai berdasarkan hasil tes tertulisnya. Untuk menguji keabsahan data penelitian digunakan triangulasi data, yaitu triangulasi waktu dengan memberikan tes kemampuan berpikir kreatif matematis yang kedua dengan soal yang sama tetapi dalam waktu yang berbeda.

Analisis data penelitian menggunakan metode perbandingan tetap atau constant comparative method. Dalam penelitian ini, analisis data dilakukan dengan membandingkan secara tetap satu datum dengan datum yang lain, dan kemudian secara tetap membandingkan kategori dengan kategori lainnya (Moleong, 2013, p. 287). Langkah analisisnya meliputi: (1) reduksi data dan kategorisasi dengan menyiapkan data-data yang diperlukan dan membuang data yang tidak diperlukan untuk keperluan analisis; (2) penyajian data, dimana data yang sudah direduksi disajikan untuk kepentingan analisis profil kemampuan berpikir kreatif matematis berdasarkan kategori gaya kognitifnya; dan (3) penarikan kesimpulan dan verifikasi, dimana data yang sudah disajikan akan dibandingkan dan dianalisis berdasarkan indikator tes kemampuan berpikir kreatif matematis dan disesuaikan dengan kategori gaya kognitif masing-masing subjek penelitian. 

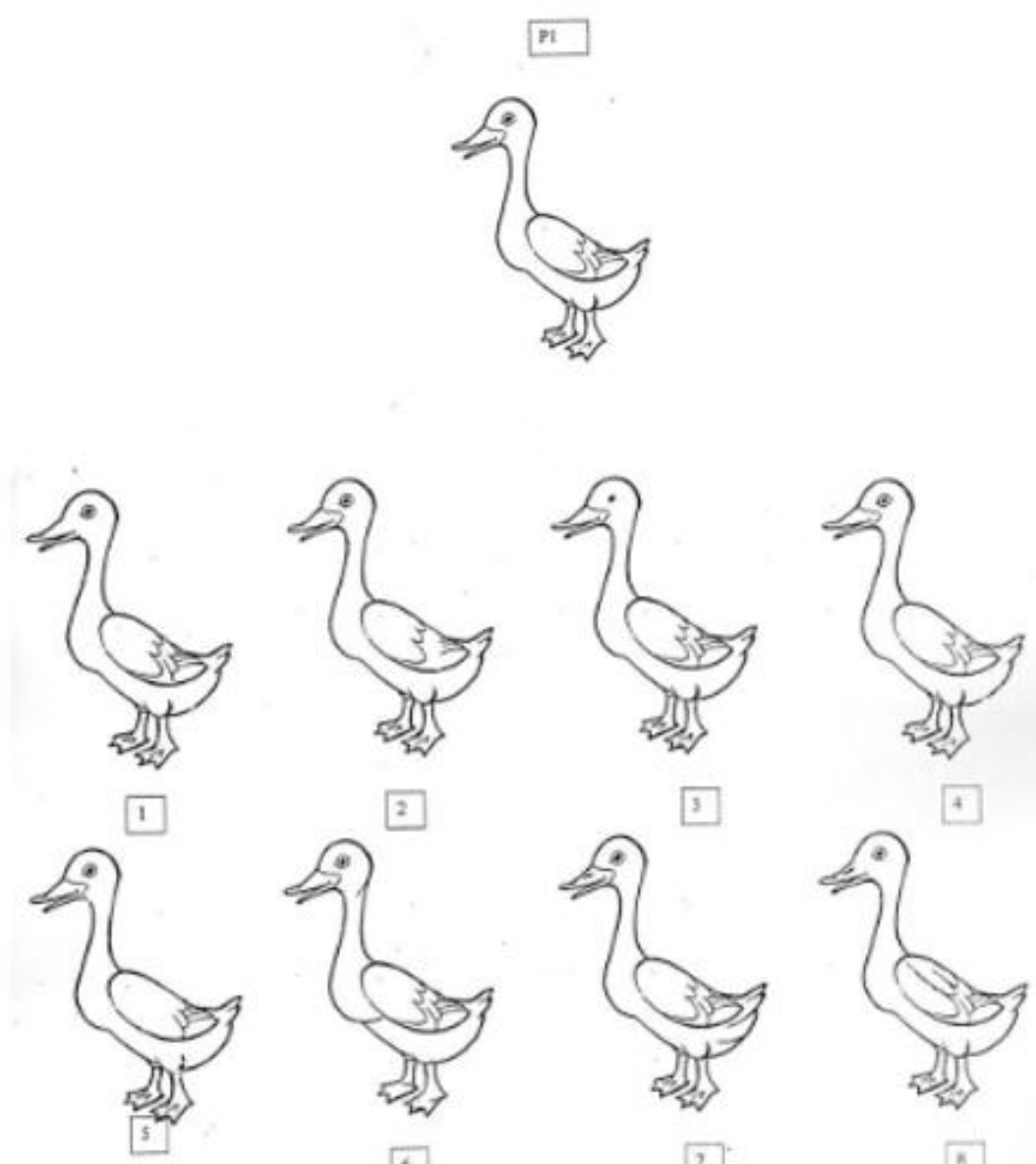

Gambar 1. Contoh Soal Matching Familiar Figure Test

\section{HASIL DAN PEMBAHASAN}

\section{Hasil Pengukuran Gaya Kognitif}

Mahasiswa calon guru diberikan tes MFFT (Matching Familiar Figure Test) yang telah dirancang dan dikembangkan oleh Warli (2010). MFFT terdiri atas 13 soal bergambar ditambah dengan 2 soal percobaan. Mahasiswa mengisi MFFT dengan memilih jawaban sampai diperoleh jawaban benar. Peneliti mencatat banyak waktu yang diperlukan oleh mahasiswa untuk memilih jawaban pertama kali dan banyak frekuensi memilih sampai diperoleh jawaban yang benar. Waktu yang dibutuhkan untuk memperoleh jawaban pertama kali dicatat dalam satuan detik. Selanjutnya waktu dan frekuensi menjawab semua mahasiswa yang mengisi MFFT dihitung nilai mediannya. Setelah dihitung hasil pengisian MFFT diperoleh pengelompokan gaya kognitif seperti disajikan pada Gambar 2.

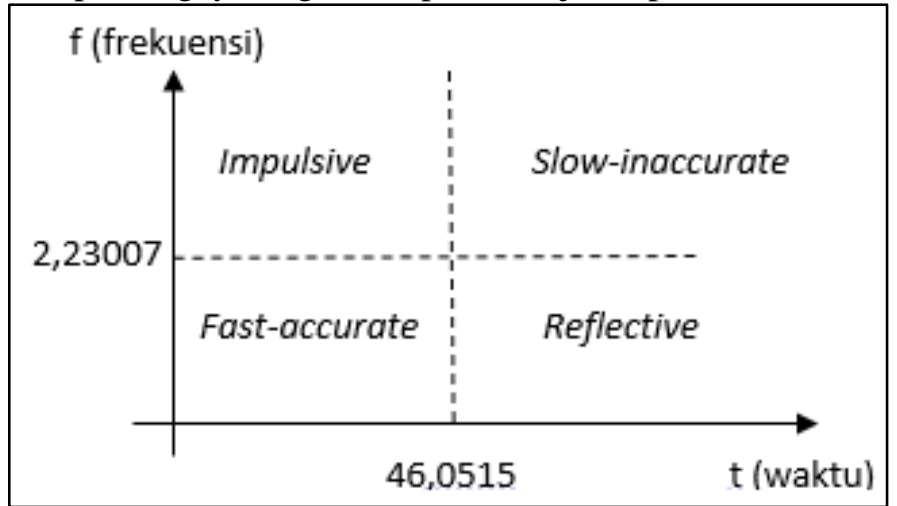

Gambar 2. Pengelompokan Gaya Kognitif Reflective dan Impulsive 
Hasil tes MFFT dihitung berdasarkan banyaknya waktu yang dibutuhkan pada saat pertama kali menjawab dan banyaknya frekuensi jawaban sampai diperoleh jawaban yang benar. Waktu dan frekuensi yang dibutuhkan oleh masing-masing calon subjek penelitian selanjutnya dihitung nilai mediannya untuk menentukan mahasiswa yang memiliki gaya kognitif reflective, impulsive, fast accurate atau slow inaccurate. Berdasarkan Gambar 1, mahasiswa dengan gaya kognitif reflective diambil dari kelompok mahasiswa yang waktu pengerjaan MFFT memiliki median waktu $(\mathrm{t}) \geq 46,0515$ dan frekuensi menjawab sampai diperoleh jawaban benar (f) $\leq 2,23007$. Mahasiswa dengan gaya kognitif reflective diambil dari mahasiswa dengan catatan waktu pengerjaan paling lama dan paling cermat (paling banyak benar) dalam menjawab seluruh butir soal. Sedangkan mahasiswa dengan gaya kognitif impulsive diambil dari kelompok mahasiswa yang waktu pengerjaan MFFT memiliki median waktu (t ) < 46,0515 dan frekuensi menjawab sampai diperoleh jawaban benar (f) $>2$ 2,23007. Mahasiswa dengan gaya kognitif impulsive adalah mahasiswa dari kelompok impulsive yang memiliki catatan waktu paling cepat dan paling tidak cermat (paling banyak salah) dalam menjawab seluruh butir soal. Setelah dikelompokkan seperti pada Gambar 1, dari 19 mahasiswa calon guru diperoleh proporsi banyak mahasiswa untuk setiap kategori gaya kognitif pada Tabel 1.

Tabel 1. Hasil Pengukuran Gaya Kognitif

\begin{tabular}{cccc}
\hline Reflective & Impulsive & Fast Accurate & Slow Accurate \\
\hline 8 orang & 5 orang & 4 orang & 2 orang \\
$42,10 \%$ & $26,31 \%$ & $21,05 \%$ & $10,52 \%$ \\
\hline
\end{tabular}

Tabel 1 menjelaskan bahwa jumlah mahasiswa dengan gaya reflective-impulsive sebanyak 13 orang $(68,41 \%)$ dan mahasiswa dengan kriteria fast accurate-slow inaccurate sebanyak 6 orang (31,57\%). Proporsi mahasiswa dengan gaya reflective dan impulsive lebih banyak jika dibandingkan dengan mahasiswa dengan kriteria cermat dan kurang akurat dalam menjawab soal. Hal ini sejalan dengan hasil penelitian Puspita dan Wijayanti (2016) yang melaporkan bahwa proporsi siswa dengan gaya kognitif reflective dan impulsive lebih banyak dibandingkan dengan siswa kriteria fast accurateslow inaccurate. Penelitian dari Warli (Shoimah et al., 2018) memberikan hasil bahwa 73,7\% siswa memiliki gaya kognitif reflective-impulsive. Sedangkan penelitian (Rozencwajg \& Corroyer, 2005) menyebutkan bahwa proporsi siswa yang memiliki gaya kognitif reflective dan impulsive adalah $76 \%$. Hal ini menunjukkan bahwa proporsi gaya kognitif reflective dan impulsive cenderung lebih besar dari pada siswa dengan gaya kognitif fast accurate-slow inaccurate.

Selanjutnya dipilih 1 subjek untuk masing-masing gaya kognitif reflective dan impulsive. Pemilihan subjek selain berdasarkan kriteria gaya kognitif reflective dan impulsive, juga memperhatikan jenis kelamin dan kemampuan awal mahasiswa. Atas dasar tersebut, mahasiswa yang terpilih sebagai subjek penelitian harus berjenis kelamin sama dan memiliki kemampuan awal yang sama pula. Subjek reflective terpilih adalah mahasiswa bernama ALR yang selanjutnya akan dikodekan dengan nama subjek S1. Sedangkan subjek impulsive terpilih adalah mahasiswa bernama SNI yang selanjutnya akan dikodekan dengan nama subjek S2. Kedua subjek terpilih berjenis kelamin perempuan.

\section{Paparan, Triangulasi, dan Penarikan Kesimpulan}

Data hasil penelitian ini berupa data hasil pengerjaan Tes Kemampuan Berpikir Kreatif Matematis (TKBKM) dan data wawancara. Data hasil wawancara oleh setiap subjek pada masing-masing kategori gaya kognitif ditranskripkan dan dipaparkan guna mengetahui kemampuan berpikir kreatif matematis mahasiswa calon guru dalam menyelesaikan masalah open-ended. Untuk memudahkan penulisan pada paparan hasil wawancara dibuat kode "Px,y,z" dan "Sx,y,z". P = pewawancara untuk subjek ke-x; S = subjek penelitian; $\mathrm{x}, \mathrm{y}, \mathrm{z}=$ kode digit setelah $\mathrm{P}$ dan $\mathrm{S}$, digit pertama menyatakan subjek ke-x $(1 \leq \mathrm{x} \leq 2)$, digit kedua menyatakan wawancara berbasis tugas ke-y $(1 \leq \mathrm{y} \leq 2)$, dan digit ketiga menyatakan urutan pertanyaan atau jawaban tertulis ke-z. Berikut adalah contoh penggunaan kode tersebut.

P1.1.1 = pewawancara untuk subjek 1, wawancara berbasis tugas ke 1, dan pertanyaan ke-1.

S1.1.1 = subjek S1, wawancara berbasis tugas ke-1, dan jawaban ke-1.

Berikut akan disajikan pemaparan data hasil tes tertulis dan wawancara TKBKM 1 dan TKBKM 2 untuk subjek yang bergaya kognitif reflective dan impulsive. 
Subjek dengan Gaya Kognitif Reflective (S1)

Subjek S1 dalam menjawab TKBKM cenderung lebih rinci dan teliti. Subjek S1 memberikan jawaban tertulis secara terurai dan cukup lengkap beserta dengan penjelasannya. Misalnya pada pertanyaan nomor 1 yang merupakan pertanyaan untuk indikator aspek kelancaran (fluency). Pertanyaan nomor 1 pada TKBKM 1 sebagai berikut: "Diketahui kubus ABCD.EFGH dengan panjang rusuk $6 \mathrm{~cm}$. Tentukan jarak titik $B$ ke diagonal ruang $A G$ dan jarak titik $B$ ke diagonal sisi $E G$ '. Data jawaban tertulis subjek S1 disajikan pada Gambar 3 dan Gambar 4, dan cuplikan wawancara pada pertanyaan nomor 1 untuk subjek S1 disajikan pada Tabel 2.

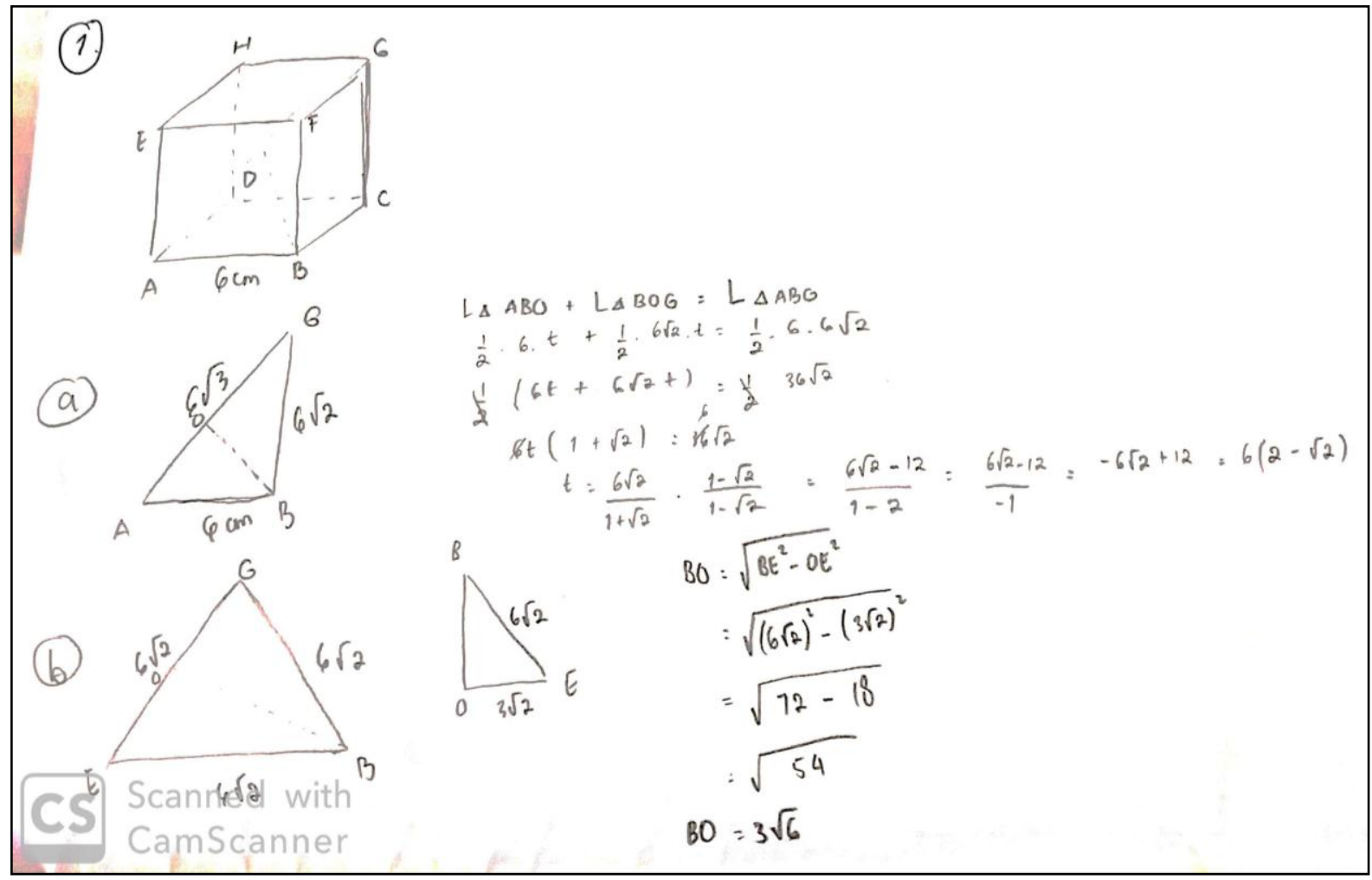

Gambar 3. Hasil Tes Tertulis Pertanyaan nomor 1 TKBKM 1

(1)

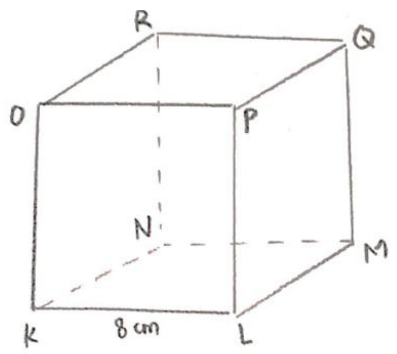

a) Jarak titik $K$ ke diagonal ruang $L R$

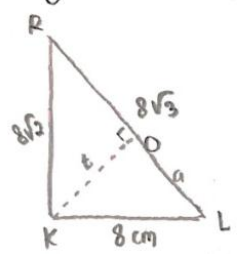

$$
\begin{aligned}
L \Delta K L O+L \Delta K R O & =L \Delta K R L \\
\frac{1}{2} a \cdot t & +\frac{1}{2} 8 \sqrt{3}-a \cdot t=\frac{1}{2} \cdot 8 \cdot 8 \sqrt{2} \\
\frac{1}{2} t(a+8 \sqrt{3}-a) & =\frac{7}{2} 8 \cdot 8 \sqrt{2} \\
8 \sqrt{3} t & =64 \sqrt{2} \\
t & =\frac{64 \sqrt{2}}{8 \sqrt{3}}=\frac{8 \sqrt{2}}{\sqrt{3}} \cdot \frac{\sqrt{3}}{\sqrt{3}}=\frac{8 \sqrt{6}}{3}
\end{aligned}
$$

b) Jarak titik $K$ ke diagonal sisi $P R$

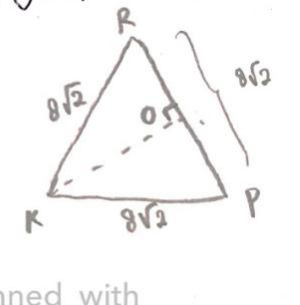

$$
\begin{aligned}
K O & =\sqrt{K R^{2}-R O^{2}} \\
& =\sqrt{(8 \sqrt{2})^{2}-(4 \sqrt{2})^{2}} \\
& =\sqrt{128-32} \\
& =\sqrt{96} \\
K O & =4 \sqrt{6}
\end{aligned}
$$

Gambar 4. Hasil Tes Tertulis Pertanyaan nomor 1 TKBKM 2 


\section{Jurnal Riset Pendidikan Matematika, 6 (2), 2019 - 156}

Asih Miatun, Nurafni Nurafni

Pertanyaan nomor 1 pada TKBKM 1 dan TKBKM 2 pada dasarnya adalah pertanyaan yang sama, hanya dibedakan pada penamaan kubus dan ukuran rusuknya saja. Gambar 3 dan Gambar 4 menunjukkan bahwa jawaban tertulis yang diberikan oleh subjek S1 pada TKBKM 1 dan TKBKM 2 menggunakan cara yang sama. Sehingga dapat dikatakan bahwa jawaban subjek S1 konsisten, sehingga dapat dinyatakan bahwa data untuk indikator menyatakan hubungan sebab akibat antar konsep matematis adalah valid.

Tabel 2. Hasil Cuplikan Wawancara Subjek S1 pada TKBKM 1 dan TKBKM 2

\begin{tabular}{cc}
\hline TKBKM 1 & TKBKM 2 \\
\hline P1.1.12: lalu di sini kamu mencari BO menggunakan & P1.2.12: lalu di sini kamu mencari KO \\
luas segitiga? & menggunakan apa? \\
S1.1.12: iya, jadi kan luas segitiga ABO ditambah & S1.2.12: saya mencari KO menggunakan luas \\
dengan luas segitiga BOG sama dengan luas & segitiga. Jadi luas segitiga KOL ditambah \\
segitiga ABG & dengan luas segitiga KOR sama dengan \\
P1.1.13: (menunjuk gambar) jadi di sini tinggi yang & luas segitiga KLR \\
kamu maksud bukan BO tetapi tinggi masing- & P1.2.13: (menunjuk gambar) jadi di sini tinggi \\
masing segitiga ABO dan BOG itu berbeda? & yang kamu maksud bukan KO tetapi tinggi \\
S1.1.13: oh iya ya, saya alasnya menggunakan alas & masing-masing segitiga KOL dan KOR itu \\
yang berbeda berarti tingginya juga berbeda & berbeda? \\
ya ... & S1.2.13: iya saya alasnya menggunakan alas yang \\
P1.1.14: O itu di tengah-tengah AG tidak? & berbeda berarti tingginya juga berbeda \\
S1.1.14: O tidak di tengah AG & ya. Masih sama seperti jawaban \\
P1.1.15: kenapa? & sebelumnya bu, saya masih bingung \\
S1.1.15: karena dia bukan segitiga sama kaki & bagian ini \\
\hline
\end{tabular}

Indikator untuk soal nomor 1 adalah kelancaran (fluency). Berdasarkan hasil wawancara pada Tabel 2 terlihat bahwa subjek mampu menghubungkan konsep matematis yang dipilihnya dengan masalah yang disajikan. Subjek S1 mampu menjelaskan dengan baik jawaban yang dituliskan ketika diminta menjelaskan oleh peneliti. Pertanyaan nomor 1 terdiri atas poin a dan b. Terlihat dari jawaban 1a bahwa subjek S1 menjawab pertanyaan menggunakan strategi dan mampu menjelaskan dengan baik jawaban yang dituliskannya, terlepas dari jawaban tersebut benar ataupun salah. Untuk pertanyaan 1a subjek mampu menjelaskan hubungan sebab akibat dan keterkaitan antar konsepnya, walaupun jawaban yang ditulisnya masih salah. Sedangkan untuk pertanyaan 1b subjek S1 mampu menjelaskan hubungan dan keterkaitan antar konsepnya dengan baik dan bisa memberikan jawaban yang benar.

Pada indikator kedua yaitu aspek keluwesan (flexibility), subjek bisa memahami pertanyaan dengan baik dan bisa menyelesaikan pertanyaan yang diberikan dengan baik. Pertanyaan nomor 2 adalah "Diketahui kubus KLMN.OPQR memiliki panjang rusuk $6 \mathrm{~cm}$. Tentukan jarak titik $R$ ke diagonal sisi KM! (Gunakan lebih dari satu cara)". Pada indikator ini subjek diminta menyelesaikan masalah yang berkaitan dengan jarak titik dengan garis tapi menggunakan lebih dari satu cara. Subjek S1 baru bisa menggunakan satu cara untuk menyelesaikan masalah tersebut.

Indikator ketiga yaitu pada aspek keluwesan menggunakan strategi baru, unik, dan tidak biasa untuk menyelesaikan masalah matematika. Subjek dengan gaya kognitif reflective belum mampu menyelesaikan masalah yang diberikan dengan menggunakan strategi baru, unik, dan tidak biasa. Masalah yang diberikan masih sama tentang jarak titik pada garis bidang ruang, tetapi dengan sedikit variasi titik pada garisnya. Subjek reflective belum bisa menemukan strategi penyelesaian yang unik untuk menyelesaikan pertanyaan untuk indikator keluwesan.

Indikator terakhir yaitu indikator aspek keterincian yang diukur melalui pertanyaan nomor 3 berikut: "Diketahui balok memiliki perbandingan panjang rusuk 3: 6: 2. Panjang diagonal ruangnya $21 \mathrm{~cm}$. Tentukan volume balok tersebut!'. Subjek reflective mampu menjelaskan jawaban atau penyelesaian dari masalah dengan baik. Jawaban yang diberikan subjek $\mathrm{S} 1$ sudah sangat jelas dan terperinci. Setiap langkah jawaban yang dituliskannya mampu dijelaskan dengan baik. Subjek S1 mampu menjelaskan secara detail tentang penerapan konsep matematis yang digunakan dalam menjawab pertanyaan. Subjek S1 mampu menjelaskan secara terperinci, runtut, koheren terhadap suatu prosedur matematis dan jawaban.

Selain mampu menjelaskan secara terinci dan jelas dalam menjawab pertanyaan nomor 3, subjek S1 juga menggunakan cara yang unik dan tidak biasa dalam menjawab pertanyaan tersebut. Salah satu yang menarik pada penyelesaian subjek S1 adalah subjek mampu menggunakan cara unik atau tidak 
biasa seperti yang kebanyakan orang lakukan. Jika biasanya dalam penyelesaian soal jenis ini orang akan mencari ukuran panjang lebar dan tinggi terlebih dahulu, sedangkan subjek reflective mencari nilai pembanding dari diagonal ruang yang diketahui terlebih dahulu. Jawaban tertulis subjek S1 dari pertanyaan nomor 3 disajikan pada Gambar 5 dan Gambar 6.

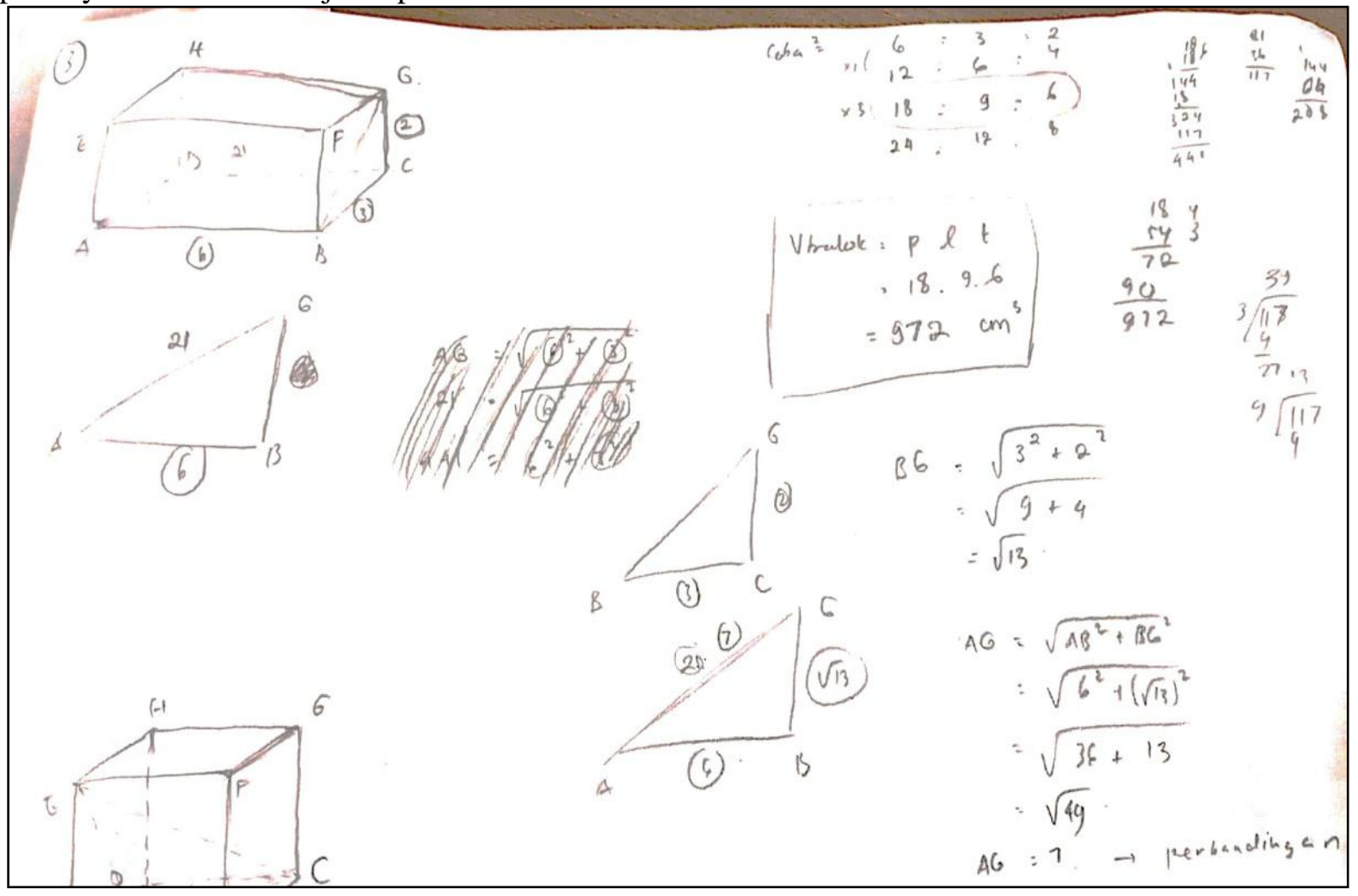

Gambar 5. Jawaban Tertulis Subjek S1 pada Pertanyaan Nomor 3 TKBKM 1

(3)

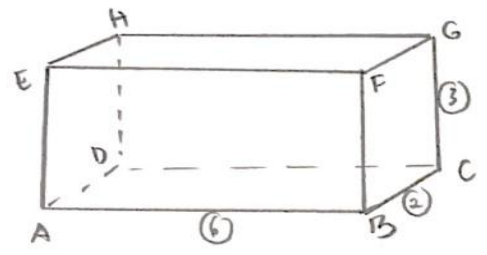

Tentukan volume balok!

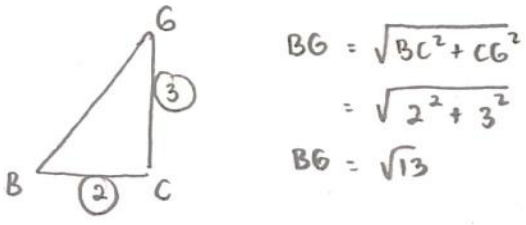

volume baluk $=A B \times B C \times C G$

$=18 \mathrm{~cm} \times 6 \mathrm{~cm} \times 9 \mathrm{~cm}$

Scanned with $972 \mathrm{~cm}^{3}$

CamScanne

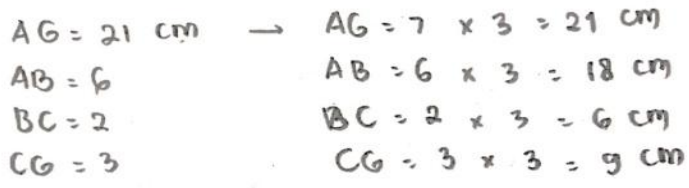

$A B=6$

$B C=2$

$C G=3$

$A B=6 \times 3=18 \mathrm{~cm}$

$B C=2 \times 3=6 \mathrm{~cm}$

$C_{6}=3 \times 3=9 \mathrm{~cm}$

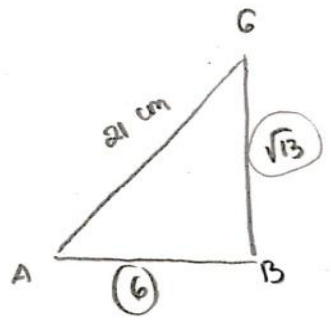

$A G=\sqrt{A B^{2}+B G^{2}}$

$=\sqrt{6^{2}+(\sqrt{13})^{2}}$

$=\sqrt{36+13}$

$=\sqrt{49}$

$A G=7 \rightarrow$ perbandingan

Gambar 6. Jawaban Tertulis Subjek S1 pada Pertanyaan Nomor 3 TKBKM 2

Pertanyaan nomor 3 untuk TKBKM 1 dan TKBKM 2 adalah pertanyaan yang sama. Subjek S1 memberikan cara pengerjaan yang sama untuk menjawab pertanyaan nomor 3 pada TKBKM 1 dan TKBKM 2 seperti yang terlihat pada Gambar 5 dan Gambar 6. Dari gambar tersebut terlihat jelas bahwa 
jawaban yang diberikan oleh subjek S1 pada TKBKM 1 dan TKBKM 2 adalah jawaban yang sama. Hanya pada jawaban TKBKM 2 subjek S1 menuliskan dengan lebih rapi jawabannya. Berdasarkan Gambar 5 dan Gambar 6 dapat dipahami bahwa jawaban yang diberikan oleh subjek S1 baik pada TKBKM 1 dan TKBKM 2 selalu konsisten. Hal yang sama juga terlihat dari hasil wawancara. Dengan demikian dapat disimpulkan bahwa data pemahaman kemampuan subjek S1 ketika menjelaskan secara terperinci, runtut, koheren terhadap suatu prosedur matematis dan jawaban adalah valid.

Subjek dengan Gaya Kognitif Impulsive (S2)

Subjek S2 dalam menjawab TKBKM cenderung lebih rinci dan teliti. Subjek S2 memberikan jawaban tertulis secara terurai dan cukup lengkap beserta dengan penjelasannya. Misalnya pada pertanyaan nomor 1 yang merupakan pertanyaan untuk indikator aspek kelancaran (fluency). Pertanyaan nomor 1 pada TKBKM 1 sebagai berikut: "Diketahui kubus ABCD.EFGH dengan panjang rusuk $6 \mathrm{~cm}$. Tentukan jarak titik $B$ ke diagonal ruang $A G$ dan jarak titik $B$ ke diagonal sisi $E G$ ". Data jawaban tertulis subjek S2 untuk pertanyaan nomor 1 disajikan pada Gambar 7 dan Gambar 8, sedangkan cuplikan wawancara pada pertanyaan nomor 1 untuk subjek S2 disajikan pada Tabel 3.

Pertanyaan nomor 1 pada TKBKM 1 dan TKBKM 2 adalah pertanyaan dengan tipe yang sama. Hanya berbeda pada penamaan kubus dan ukuran rusuknya saja. Pada Gambar 7 dan Gambar 8 terlihat bahwa jawaban yang diberikan subjek S2 selalu konsisten. Hal ini menunjukkan bahwa data untuk aspek kelancaran (fluency) tentang bagaimana subjek menyatakan hubungan sebab akibat terhadap konsep matematis yang digunakannya adalah valid. Selain jawaban tertulis yang diberikan, terdapat cuplikan wawancara untuk subjek S2 dalam menjawab pertanyaan nomor 1 pada TKBKM 1 dan TKBKM 2 disajikan pada Tabel 3 .

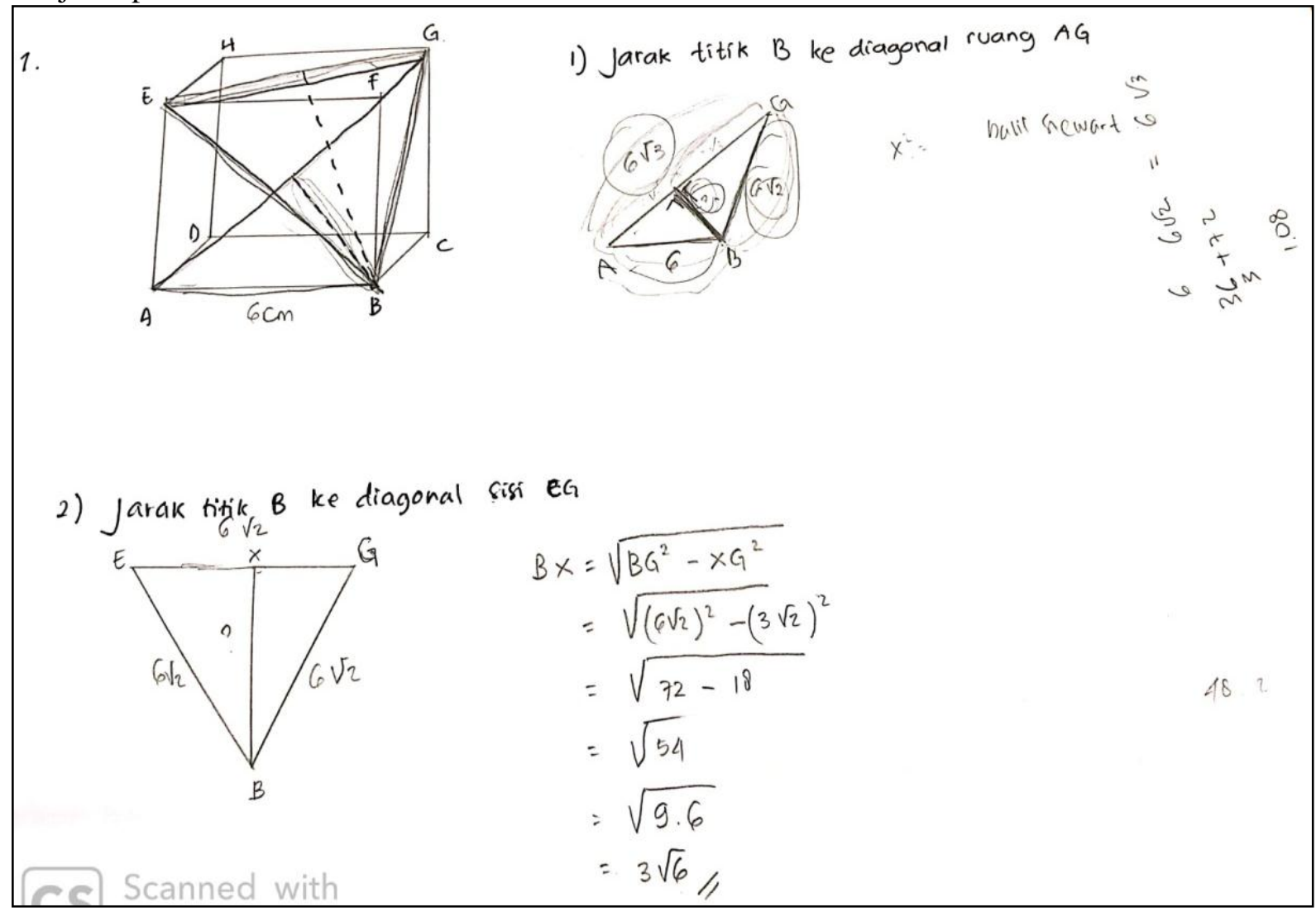

Gambar 7. Jawaban Tertulis Subjek S2 Pertanyaan nomor 1 TKBKM 1 


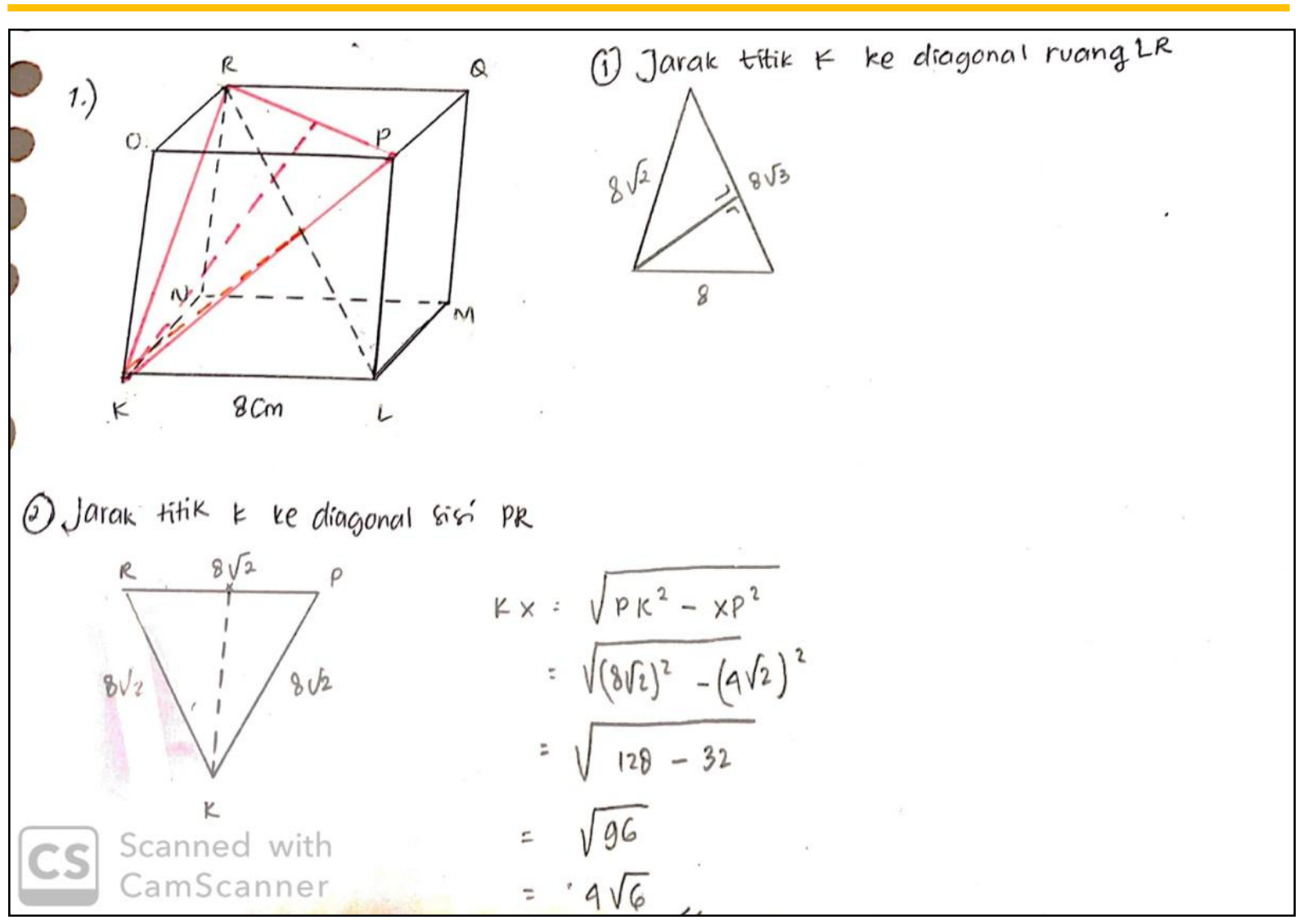

Gambar 8. Jawaban Tertulis Subjek S2 Pertanyaan nomor 1 TKBKM 2

Tabel 3. Hasil Cuplikan Wawancara Subjek S2 pada Pertanyaan Nomor 1 TKBKM1 dan TKBKM 2

\begin{tabular}{|c|c|}
\hline TKBKM 1 & TKBKM 2 \\
\hline $\begin{array}{l}\text { P2.1.15: garis B ke AG memotong AG tepat di tengah } \\
\text { nggak? }\end{array}$ & $\begin{array}{l}\text { P2.2.15: garis } K \text { ke LR memotong LR tepat di tengah } \\
\text { nggak? }\end{array}$ \\
\hline S2.1.15: dia tidak memotong AG tepat di tengah & S2.2.15: K tidak memotong LR tepat di tengah \\
\hline P2.1.16: memotong nggak? & P2.2.16: memotong nggak? \\
\hline $\begin{array}{l}\text { S2.1.16: enggak (mahasiswa memperlihatkan } \\
\text { gambar) }\end{array}$ & $\begin{array}{l}\text { S2.2.16: tidak (mahasiswa memperlihatkan gambar) } \\
\text { P2.2.17: yakin tidak? }\end{array}$ \\
\hline P2.1.17: yakin tidak? & S2.2.17: kalau memotong LR tepat di tengah-tengah \\
\hline $\begin{array}{l}\text { S2.1.17: kalau memotong AG tepat di tengah-tengah } \\
\text { tidak }\end{array}$ & $\begin{array}{c}\text { tidak } \\
\text { P2.2.18: } 8 \text { akar } 3 \text { dapatnya dari mana? }\end{array}$ \\
\hline P2.1.18: 6 akar 3 dapatnya dari mana? & S2.2.18: dari segitiga siku-siku tadi,LR kan diagonal \\
\hline $\begin{array}{l}\text { S2.1.18: dari segitiga siku-siku tadi,AG kan diagonal } \\
\text { ruang juga }\end{array}$ & $\begin{array}{l}\text { ruang juga } \\
\text { P2.2.19: lalu jarak K ke titik } O \text { udah dicari belum? }\end{array}$ \\
\hline $\begin{array}{l}\text { P2.1.19: lalu jarak B ke titik O sudah dicari belum? } \\
\text { S2.1.19: belum, saya lupa caranya }\end{array}$ & S2.2.19: belum, saya lupa caranya $B u$ \\
\hline
\end{tabular}

Indikator soal nomor 1 adalah kelancaran (fluency), subjek S2 masih belum bisa memilih konsep yang akan digunakan untuk menyelesaikan masalah tersebut. Terlihat dari jawaban tertulis subjek S2 masih belum bisa menyelesaikan masalah yang diberikan dengan benar. Selain itu ketika diwawancara subjek S2 juga kebingungan untuk menjelaskan jawaban yang ditulisnya. Cuplikan wawancara pada Tabel 3 dan hasil tes tertulis menunjukkan kekonsistenan subjek S2 dalam menjawab pertanyaan. Pertanyaan nomor 1 terdiri atas poin a dan b. Pada pertanyaan a terlihat bahwa subjek S2 belum bisa menemukan jawaban dari pertanyaan yang diberikan. Sedangkan pada soal b subjek S2 mampu memberikan jawabannya dengan benar dan ketika diwawancara mampu menjelaskan dengan baik.

Pada indikator kedua yaitu aspek keluwesan (flexibility) subjek bisa memahami pertanyaan dengan baik dan bisa menyelesaikan pertanyaan yang diberikan dengan baik. Pada indikator ini subjek diminta menyelesaikan masalah yang berkaitan dengan jarak titik dengan garis, tetapi menggunakan 
lebih dari satu cara. Sama dengan subjek S1, subjek S2 juga baru bisa menggunakan satu cara untuk menyelesaikan pertanyaan tersebut.

Pada indikator ketiga yaitu pada aspek keluwesan menggunakan strategi baru, unik, dan tidak biasa untuk menyelesaikan masalah matematika, subjek impulsive belum mampu menyelesaikan masalah yang diberikan dengan menggunakan strategi baru, unik, dan tidak biasa. Masalah yang diberikan masih sama tentang jarak titik pada garis bidang ruang, tetapi dengan sedikit variasi titik pada garisnya. Baru sebagian jawaban subjek S2 yang benar dan sesuai dengan konsep matematis.

Pada indikator terakhir yaitu indikator keterincian, subjek S2 belum mampu menjelaskan jawaban atau penyelesaian dari masalah dengan baik. Subjek S2 masih kesulitan menentukan ukuran-ukuran panjang, lebar, dan tinggi dari balok. Subjek S2 masih kesulitan dalam menerapkan hal-hal yang diketahui untuk menyelesaikan masalah yang ada. Dengan demikian dapat disimpulkan bahwa subjek S2 belum mampu menjelaskan secara terperinci, runtut, dan koheren prosedur matematis dan jawaban yang diperolehnya.

Dari 4 pertanyaan yang diberikan, tidak ada satu pertanyaan pun yang bisa dijawab oleh subjek S2 dengan sempurna. Subjek S2 cenderung terburu-buru dalam menjawab pertanyaan yang ada dan kurang cermat. Jawaban-jawaban yang diberikan oleh subjek S2 hanya menjawab setengah pertanyaan saja, dan hal ini menunjukkan bahwa subjek impulsive atau subjek S2 kemampuan berpikir kreatifnya masih kurang. Jawaban subjek S2 pada pertanyaan nomor 3 untuk indikator keterincian disajikan pada Gambar 9.

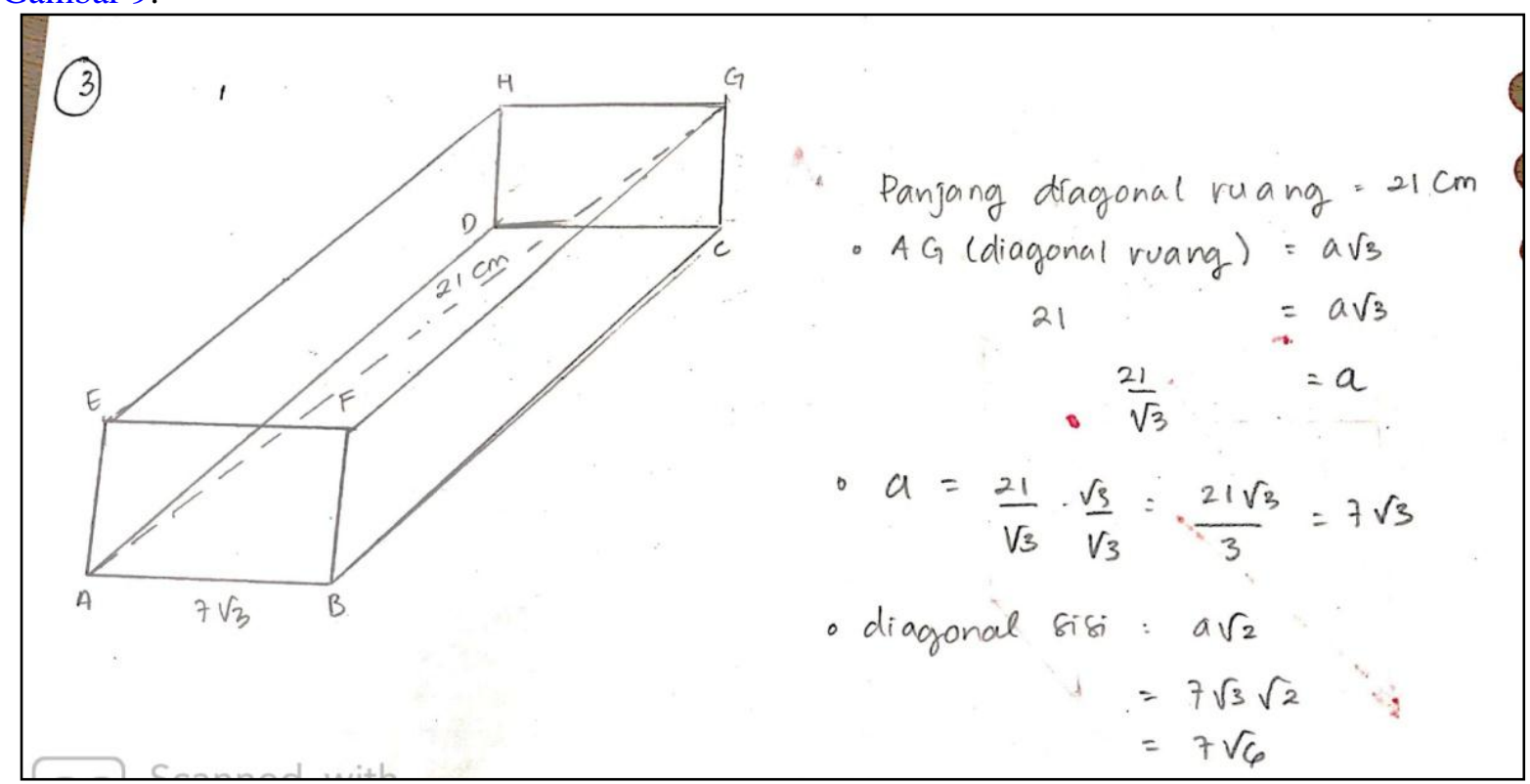

Gambar 9. Jawaban Tertulis Subjek S2 pada Pertanyaan nomor 3 TKBKM 2

Pertanyaan nomor 3 untuk TKBKM 1 dan TKBKM 2 adalah pertanyaan yang sama. Jawaban yang diberikan oleh subjek S2 pun sama. Pada Gambar 9 hanya disajikan jawaban subjek S2 untuk TKBKM 2 saja. Jawaban tertulis tersebut menunjukkan bahwa subjek S2 belum mampu menjawab pertanyaan untuk indikator aspek keterincian dengan baik. Dari penjelasan saat wawancara subjek S2 menyebutkan bahwa masih kesulitan dalam menyelesaikan pertanyaan nomor 3.

\section{Deskripsi Kemampuan Berpikir Kreatif Matematis Subjek Ditinjau dari Gaya kognitif Reflective dan Impulsive}

Sesuai dengan tema penelitian yaitu profil kemampuan berpikir kreatif matematis mahasiswa calon guru dalam menyelesaikan masalah open-ended ditinjau dari gaya kognitif reflective dan impulsif, berikut akan disajikan deskripsi secara lebih jelas pada setiap indikator kemampuan berpikir kreatif matematis dan pada setiap kategori gaya kognitif, seperti disajikan pada Tabel 4.

Tabel 4 menjelaskan secara lebih ringkas perbedaan kemampuan berpikir kreatif matematis subjek dengan masing-masing gaya kognitif reflective dan impulsive. Dapat dilihat dari Tabel 4 bahwa subjek reflective mampu menguasai indikator kemampuan berpikir kreatif matematis lebih banyak dibandingkan dengan subjek impulsive. Subjek reflective dan impulsive diberikan tes kemampuan 
berpikir kreatif matematis dalam waktu bersamaan. TKBKM terdiri atas 4 pertanyaan dengan waktu pengerjaan selama 90 menit. Subjek reflective mengusai indikator kemampuan berpikir kreatif matematis lebih banyak dimungkinkan karena subjek reflective memikirkan kemungkinan jawaban dan menyusun konsep matematis yang akan digunakannya terlebih dahulu sedangkan subjek impulsive terlalu terburu-buru ketika mengerjakan soal. Subjek impulsive mengerjakan dalam waktu 58 menit sedangkan subjek reflective mengerjakan dalam waktu 85 menit. Hal ini sejalan dengan hasil penelitian dari (Aprilia et al., 2015; Rozencwajg \& Corroyer, 2005) yang menyebutkan bahwa siswa reflektif selalu berpikir dahulu jika dihadapkan dengan masalah atau pertanyaan, sedangkan siswa impulsive cenderung spontan dalam menjawab pertanyaan dan menulis semua ide maupun rencana yang ada dalam pikirannya di lembar jawaban. Subjek reflective cenderung memikirkan terlebih dahulu benar atau salahnya jawaban yang akan ditulis, sedangkan subjek impulsive spontan dalam menjawab pertanyaan dan tidak hati-hati sehingga jawaban yang diberikan masih terdapat kesalahan. Selain itu subjek impulsive juga cenderung lebih cepat menyerah ketika tidak bisa mengerjakan soal, hal ini terlihat dari hasil wawancara pada subjek impulsive, seperti yang ditunjukkan pada cuplikan wawancara S2.1.19 dan S2.2.19.

Tabel 4. Deskripsi Kemampuan Berpikir Kreatif Matematis ditinjau dari Gaya Kognitif

\begin{tabular}{|c|c|}
\hline Gaya Kognitif Reflective & Gaya Kognitif Impulsive \\
\hline \multicolumn{2}{|c|}{ Aspek kelancaran (fluency) } \\
\hline $\begin{array}{l}\text { Subjek reflective mampu menjelaskan secara rinci dan } \\
\text { jelas jawaban yang dituliskannya. Subjek pada umum- } \\
\text { nya sudah menjelaskan dengan baik hubungan sebab } \\
\text { akibat dan keterkaitan antar konsep yang diketahuinya, } \\
\text { walaupun jawaban yang ditulisnya masih salah. }\end{array}$ & $\begin{array}{l}\text { Subjek impulsive mampu menjelaskan secara rinci dan } \\
\text { jelas sebagian jawaban yang dituliskannya. Subjek } \\
\text { mampu menjelaskan hubungan sebab akibat pada } \\
\text { jawaban yang dituliskannya dengan baik dan benar, } \\
\text { namun sebagian jawaban lainnya belum dapat dijelas- } \\
\text { kan hubungan sebab akibatnya. }\end{array}$ \\
\hline \multicolumn{2}{|c|}{ Aspek keluwesan (flexibility) } \\
\hline $\begin{array}{l}\text { Subjek reflective belum mampu menyelesaikan masa- } \\
\text { lah yang diberikan menggunakan lebih dari satu cara. } \\
\text { Hanya satu cara yang digunakan subjek reflective untuk } \\
\text { menyelesaikan masalah yang diberikan. }\end{array}$ & $\begin{array}{l}\text { Subjek impulsive belum mampu menyelesaikan masa- } \\
\text { lah yang diberikan menggunakan lebih dari satu cara. } \\
\text { Hanya satu cara yang digunakan subjek impulsive untuk } \\
\text { menyelesaikan masalah yang diberikan. }\end{array}$ \\
\hline \multicolumn{2}{|c|}{ Aspek kebaruan (originality) } \\
\hline $\begin{array}{l}\text { Subjek reflective belum mampu menyelesaikan masa- } \\
\text { lah yang diberikan dengan menggunakan strategi baru, } \\
\text { unik, dan tidak biasa. }\end{array}$ & $\begin{array}{l}\text { Subjek impulsive belum mampu menyelesaikan masa- } \\
\text { lah yang diberikan dengan menggunakan strategi baru, } \\
\text { unik, dan tidak biasa, dan hanya sebagian jawaban } \\
\text { subjek yang benar dan sesuai dengan konsep matematis. }\end{array}$ \\
\hline \multicolumn{2}{|c|}{ Aspek keterincian (elaboration) } \\
\hline $\begin{array}{l}\text { Jawaban yang diberikan subjek reflective sudah sangat } \\
\text { jelas dan terperinci. Setiap langkah jawaban yang } \\
\text { dituliskannya mampu dijelaskan dengan baik. Subjek } \\
\text { mampu menjelaskan secara detail tentang penerapan } \\
\text { konsep matematis yang digunakan dalam menjawab } \\
\text { pertanyaan. Subjek reflective mampu menjelaskan seca- } \\
\text { ra terperinci, runtut, koheren terhadap suatu prosedur } \\
\text { matematis dan jawaban. Subjek mampu menggunakan } \\
\text { cara unik dalam menyelesaikan masalah yang meng- } \\
\text { ukur aspek keterincian. }\end{array}$ & $\begin{array}{l}\text { Subjek impulsive belum mampu menjelaskan secara } \\
\text { terperinci, runtut, dan koheren terhadap suatu prosedur } \\
\text { matematis dan jawaban yang dituliskan. Subjek juga } \\
\text { belum mampu menyelesaikan masalah yang mengukur } \\
\text { aspek keterincian. }\end{array}$ \\
\hline
\end{tabular}

Dari hasil yang telah diuraikan pada Tabel 4, terlihat bahwa indikator kemampuan berpikir kreatif belum sepenuhnya dikuasai oleh subjek penelitian. Terutama pada indikator kebaruan dan keluwesan. Hal ini sejalan dengan hasil penelitian (Rochmad et al., 2018) yang melaporkan bahwa mahasiswa pendidikan matematika masih mengalami kesulitan dalam berpikir kreatif dan kritis. Pada indikator keluwesan, subjek penelitian sudah bisa menyelesaikan masalah yang diberikan, tetapi hanya menggunakan satu cara saja, padahal tujuan dari indikator keluwesan adalah agar siswa mampu menyelesaikan masalah dengan berbagai macam cara. Pada indikator kebaruan, tidak ada satu pun dari subjek penelitian yang bisa menyelesaikan masalah dengan benar, hal ini sejalan dengan hasil penelitian Wahyudi et al. (2017) yang melaporkan bahwa aspek kemampuan berpikir kreatif yang masih rendah adalah flexibility dan originality. Puspitasari et al. (2018) dalam penelitiannya menyebutkan bahwa berpikir kreatif membutuhkan kepekaan terhadap masalah, bisa mempertimbangkan informasi yang diberikan dan mampu 
menentukan langkah-langkah penyelesaian masalah yang dihadapi. Hal ini terlihat dari subjek reflective yang mengusai indikator kemampuan berpikir kreatif lebih baik dibandingkan dengan subjek impulsive, karena subjek impulsive cenderung spontan dan tidak berpikir lama dalam menyelesaikan masalah yang diberikan.

Menjadi catatan peneliti bahwa ternyata kemampuan berpikir kreatif matematis mahasiswa calon guru masih perlu ditingkatkan. Seperti halnya tujuan penelitian ini untuk mengetahui bagaimana kemampuan berpikir kritis mahasiswa calon guru ditinjau dari gaya kognitif, maka temuan penelitian ini bisa menjadi landasan sekaligus petunjuk bagi para pendidik atau dosen untuk memberikan perhatian atau perlakuan khusus pada aspek kemampuan berpikir mana saja yang perlu ditingkatkan. Beberapa penelitian (Apino \& Retnawati, 2017a, 2017b; Hu et al., 2017; Muzayyanah \& Wutsqa, 2019) merekomendasikan bahwa model pembelajaran creative problem solving dapat dijadikan salah satu alternatif untuk mengembangkan kreativitas siswa.

\section{SIMPULAN}

Dari hasil penelitian dan pembahasan, dapat disimpulkan beberapa hal. Pada mahasiswa calon guru dengan gaya kognitif reflective, aspek berpikir kreatif yang mampu dicapai dengan baik adalah kelancaran (fluency) dan aspek keterincian (elaboration). Pada aspek kelancaran mahasiswa mampu menjawab semua pertanyaan, walaupun masih ada kesalahan dalam menjawab. Untuk aspek keterincian mahasiswa calon guru dengan gaya kognitif reflective mampu menjawab dengan sempurna, sedangkan untuk aspek keluwesan dan kebaruan belum dipenuhi dengan baik. Pada mahasiswa calon guru dengan gaya kognitif impulsive, aspek kelancaran, keluwesan, kebaruan dan keterincian belum dipenuhi dengan baik. Pada aspek kelancaran mahasiswa calon guru dengan gaya kognitif impulsive belum bisa menjawab benar pertanyaan secara lengkap. Namun pada aspek kebaruan, jawaban yang diberikan oleh mahasiswa calon guru dengan gaya kognitif impulsive lebih baik dari pada jawaban yang diberikan mahasiswa calon guru dengan gaya kognitif reflective. Pada indikator keluwesan (flexibility) baik mahasiswa calon guru dengan gaya kognitif impulsive maupun reflective hanya menjawab dengan satu cara saja, meskipun diminta menjawab dengan lebih dari satu cara.

Dengan melihat profil kemampuan berpikir kreatif matematis dari mahasiswa calon guru, diharapkan pada penelitian selanjutnya dapat dianalisis metode yang tepat untuk meningkatkan kemampuan berpikir kreatif matematis. Implikasi dari temuan penelitian ini adalah kedepannya agar dapat dikembangkan berbagai model pembelajaran yang dapat melatihkan kemampuan berpikir kreatif, baik untuk guru, calon guru, maupun siswa. Selain itu, dampak dari perbedaan gaya kognitif terhadap kemampuan berpikir kreatif juga perlu diselidiki dengan menggunakan desain dan pendekatan penelitian lainnya, sehingga kedepannya dapat dipilih intervensi atau perlakuan yang tepat untuk meningkatkan kemampuan berpikir kreatif.

\section{DAFTAR PUSTAKA}

Apino, E., \& Retnawati, H. (2017a). Model pembelajaran creative problem solving dalam pembelajaran matematika SMA. In Desain pembelajaran matematika untuk melatihkan higher order thinking skills (pp. 60-118). UNY Press.

Apino, E., \& Retnawati, H. (2017b). Developing instructional design to improve mathematical higher order thinking skills of students. Journal of Physics: Conference Series, 812(1). https://doi.org/10.1088/1742-6596/812/1/012100

Aprilia, N. C., Sunardi, S., \& Trapsilasiwi, D. (2015). Proses berpikir siswa gaya kognitif reflektif dan impulsif dalam memecahkan masalah matematika di kelas VII SMPN 11 Jember. Jurnal Edukasi, 2(3), 31-37. https://doi.org/10.19184/jukasi.v2i3.6049

Apriliani, L. R., Suyitno, H., \& Rochmad, R. (2016). Analyze of mathematical creative thinking ability based on math anxiety in creative problem solving model with SCAMPER technique. CMSE: Contribution of Mathematics and Science Research for Sustainable Life in Facing Global Challenge, 3(1), 131-141. https://journal.unnes.ac.id/sju/index.php/icmse/article/view/13397

Ariani, N. M. D., Candiasa, I. M., \& Marhaeni, A. A. I. N. (2014). Pengaruh implementasi open-ended problem dalam pembelajaran matematika terhadap kemampuan pemecahan masalah dengan pengendalian kemampuan penalaran abstrak. Jurnal Penelitian Dan Evaluasi Pendidikan 
Indonesia, 4(1). https://doi.org/10.23887/jpepi.v4i1.1167

Ayllón, M. F., Gómez, I. A., \& Ballesta-Claver, J. (2016). Mathematical thinking and creativity through mathematical problem posing and solving. Journal of Educational Psychology - Propositos y Representaciones, 4(1), 169-218. https://doi.org/10.20511/pyr2016.v4n1.89

Azis, Y. M. (2018). Application and perspective of open ended approach to student learning outcomes in business math subject. Advances in Social Sciences Research Journal, 5(5), 7-17. https://doi.org/10.14738/assrj.55.4312

Damayanti, H. T., \& Sumardi, S. (2018). Mathematical creative thinking ability of junior high school students in solving open-ended problem. JRAMathEdu (Journal of Research and Advances in Mathematics Education), 3(1), 36-45. https://doi.org/10.23917/jramathedu.v3i1.5869

Fadiana, M. (2016). Perbedaan kemampuan menyelesaikan soal cerita antara siswa bergaya kognitif reflektif dan impulsif. JRAMathEdu (Journal of Research and Advances in Mathematics Education), 1(1), 79-89. https://doi.org/10.23917/jramathedu.v1i1.1775

Hendriana, H., \& Fadhillah, F. M. (2019). The students' mathematical creative thinking ability of junior high school through problem-solving approach. Infinity Journal, 8(1), 11-19. https://doi.org/10.22460/infinity.v8i1.p11-20

Hooda, M., \& Devi, R. (2017). Significance of cognitive style for academic achievement in aathematics. Scholarly Research Journal for Humanity Science \& English Language, 4(22), 5521-5527.

Hu, R., Xiaohui, S., \& Shieh, C.-J. (2017). A study on the application of creative problem solving teaching to statistics teaching. EURASIA Journal of Mathematics, Science and Technology Education, 13(7), 3139-3149. https://doi.org/10.12973/eurasia.2017.00708a

Kadir, K., \& Masi, L. (2014). Mathematical creative thinking skills of students junior high school in Kendari City. International Seminar on Innovation in Mathematics and Mathematics Education 1st ISIM-MED 2014, 295-306. http://eprints.uny.ac.id/id/eprint/24314

Kurniawan, H., Putri, R. I. I., \& Hartono, Y. (2018). Developing open-ended questions for surface area and volume of beam. Journal on Mathematics Education, 9(1), 157-168. https://doi.org/10.22342/jme.9.1.4640.157-168

Lahinda, Y., \& Jailani, J. (2015). Analisis proses pemecahan masalah matematika siswa sekolah menengah pertama. Jurnal Riset Pendidikan Matematika, 2(1), 148-161. https://doi.org/10.21831/jrpm.v2i1.7157

Maharani, H. R. (2014). Creative thinking in mathematics: Are we able to solve mathematical problems in a variety of way. International Conference on Mathematics, Science, and Education, 120-125.

Mihajlović, A., \& Dejić, M. (2015). Using open-ended problems and problem posing activities in elementary mathematics classroom. The 9th Mathematical Creativity and Giftedness International Conference, June, 34-40.

Moleong, L. J. (2013). Metodologi penelitian kualitatif (Ed. Rev.). PT Remaja Rosdakarya. https://doi.org/2010

Muzayyanah, A., \& Wutsqa, D. U. (2019). Effectiveness of problem posing and investigation in terms of problem solving abilities, motivation and achievement in mathematics. Annals of Mathematical Modeling, 1(2). https://doi.org/10.26486/amm.v1i2.27

Puspita, A. Y. A., \& Wijayanti, P. (2016). Profil pemecahan masalah matematika siswa pada materi segiempat ditinjau dari gaya kognitif reflektif dan impulsif. MATHEdunesa Jurnal Ilmiah Pendidikan Matematika, 3(5), 59-66. https://jurnalmahasiswa.unesa.ac.id/index.php/mathedunesa/article/view/18507

Puspitasari, L., In'am, A., \& Syaifuddin, M. (2018). Analysis of students' creative thinking in solving arithmetic problems. International Electronic Journal of Mathematics Education, 14(1), 49-60. https://doi.org/10.12973/iejme/3962

Rochmad, R., Kharis, M., Agoestanto, A., Zahid, M. Z., \& Mashuri Mashuri. (2018). Misconception as a critical and creative thinking inhibitor for mathematics education students. Unnes Journal of Mathematics Education, 7(1), 57-62. https://doi.org/10.15294/ujme.v7i1.18078

Rozencwajg, P., \& Corroyer, D. (2005). Cognitive processes in the reflective-impulsive cognitive style. 
Journal of Genetic Psychology, 166(4), 451-463. https://doi.org/10.3200/GNTP.166.4.451-466

Sanders, S. (2016). Critical and creative thinkers in mathematics classrooms. Journal of Student Engagement: Education Matters, 6(1), 19-27. https://ro.uow.edu.au/jseem/vol6/iss 1/4/

Sariningsih, R., \& Herdiman, I. (2017). Mengembangkan kemampuan penalaran statistik dan berpikir kreatif matematis mahasiswa di Kota Cimahi melalui pendekatan open-ended. Jurnal Riset Pendidikan Matematika, 4(2), 239-246. https://doi.org/10.21831/jrpm.v4i2.16685

Shoimah, R. N., Lukito, A., \& Siswono, T. Y. E. (2018). The creativity of reflective and impulsive selected students in solving geometric problems. Journal of Physics: Conference Series, 947(1), 1-6. https://doi.org/10.1088/1742-6596/947/1/012023

Siswono, T. Y. E. (2010). Leveling students' creative thinking in solving and posing mathematical problem. Journal on Mathematics Education, 1(1), 17-40. https://doi.org/10.22342/jme.1.1.794.17-40

Suastika, K. (2017). Mathematics learning model of open problem solving to develop student's creativity. International Electronic Journal of Mathematics Education, 12(3), 569-577. http://www.iejme.com/article/mathematics-learning-model-of-open-problem-solving-todevelop-students-creativity

Sudia, M., Budayasa, I. K., \& Lukito, A. (2014). Profil metakognisi siswa SMP dalam memecahkan masalah terbuka. Jurnal Ilmu Pendidikan Universitas Negeri Malang, 20(1), 86-93. http://journal.um.ac.id/index.php/jip/article/view/4382

Sudia, M., \& Lambertus, L. (2017). Profile of high school student mathematical reasoning to solve the problem mathematical viewed from cognitive style. International Journal of Education and Research, 5(6), 163-174. https://www.ijern.com/journal/2017/June-2017/14.pdf

Wahyudi, W., Waluya, S. B., Rochmad, R., \& Suyitno, H. (2017). Mathematical creative thinking ability and scaffolding process according with learning styles for pre-service teachers. Anatolian Journal of Education, 3(1), 1-12.

Warli, W. (2010). Profile creativity cognitive style reflective students and student cognitive style impulsiveness in solving geometry problems. Universitas Negeri Surabaya.

Winda, A., Sufyani, P., \& Elah, N. (2018). Analysis of creative mathematical thinking ability by using model eliciting activities (MEAs). Journal of Physics: Conference Series, 1013(1), 1-7. https://doi.org/10.1088/1742-6596/1013/1/012106

Yuniarti, Y., Kusumah, Y. S., Suryadi, D., \& Kartasasmita, B. G. (2017). The effectiveness of openended problems based analytic-synthetic learning on the mathematical creative thinking ability of pre-service elementary school teachers. International Electronic Journal of Mathematics Education, 12(7), 655-666. https://www.iejme.com/article/the-effectiveness-of-open-endedproblems-based-analytic-synthetic-learning-on-the-mathematical 